\title{
PERFORMANCE AND PEER ASSESSMENT ANALYSIS TOWARDS STUDENTS' SCIENTIFIC WORK THROUGH STEM-BASED VIRTUAL LABORATORY LEARNING
}

\author{
Ratih Permana Sari', Mauliza', and R. Ahmad Zaky El Islami2,3* \\ ${ }^{1}$ Department of Chemistry Education, Faculty of Teacher Training and Education, \\ Universitas Samudra, Kampus Meurandeh-Langsa Lama, Langsa, 24416, Indonesia \\ ${ }^{2}$ Division of Science Education, Faculty of Education, Kasetsart University, Chatuchak, \\ Bangkok, 10900, Thailand \\ ${ }^{3}$ Department of Science Education, Faculty of Teacher Training and Education, Universitas \\ Sultan Ageng Tirtayasa, Jl. Pakupatan, Serang, 42124, Indonesia \\ *E-mail: zakyislami@untirta.ac.id
}

Received: 20 October 2020; Accepted: 09 December 2020; Published: 31 December 2020

\begin{abstract}
This study aimed to analyze the application of performance and peer assessment to students' scientific work through a STEM-based virtual laboratory learning. The research design was used the One Group PretestPosttest and One-Shot Case Study. The research was carried out from July to September 2020 at Chemistry Education Department, one of the universities in Indonesia. The research subjects were chemistry education students for the 2018/2019 Academic Year with a purposive sampling technique. The research data was taken from the performance assessment observation sheet given before and after the laboratory practice learning process and the peer assessment questionnaire. The data listed on the observation sheet and questionnaire are then calculated for the percentage. Based on research results, it can be concluded that the implementation of performance and peer assessment of students' scientific work through STEM-based virtual laboratory learning are very competent criteria at $86 \%$ and competent at $84 \%$. The results of the paired sample $t$-test of students' scientific work abilities assessed using the performance assessment have a Sig. (2- tailed) the value below 0.05 , which is 0.000 , where there is a difference in the average results of initial and final observations using performance assessment through STEM-based virtual laboratory learning. One sample t-test of students' scientific work abilities assessed using performance and peer assessment has Sig. (2-tailed) values of 0.011 and 0.002 indicate that the mean score of students' scientific work is 75 .
\end{abstract}

Keywords: peer assessment, performance assessment, scientific work, STEM, virtual laboratory

DOI: http://doi.org/10.15575/jtk.v5i2.9858

\section{INTRODUCTION}

The use of internet today has become an integral part of the modern society lifestyle. The survey which conducted by the APJII (Asosiasi Penyelenggara Jasa Internet Indonesia / Indonesian Internet Service Providers Association) in 2016 showed that varsity students are the largest internet user in Indonesia with $89.7 \%$, and the second is junior and senior high school students with $69.8 \%$.
However, access to educational pages is still very lacking. A problem that needs to be addressed by educators is directing students to use internet more in the world of education (Adam, 2015).

One of the constraints is student lack ability to educational literacy culture. Most of them only make educational literacy to fulfillment of lecture assignments, not because the necessary and interests of each individual (Sari \& Pujiono, 2017). This will greatly affect the 
quality of graduates' students. Awareness of literacy culture should be instilled from the start, especially in terms of laboratory concepts.

Laboratory is a place of observation, experimentation, practice and testing of knowledge and technology concepts. During the current pandemic, face-to-face laboratory learning is very difficult. While, lecturer must continue to carry out the learning and assessment process. Therefore, the concept of laboratory can be used virtually as an effort to continue to apply the culture of educational literacy.

Virtual class, which is better known as elearning, is a form of internet use that can increase the role of students in the learning process. The use of virtual classes has now become interesting for many users, especially educators who almost entirely already use android-based smartphones. According to Sabekti \& Andriani (2019), the use of elearning has a role to complement conventional classes (face-to-face) which are conducted online, instead of replacing conventional classes. According to Jaya (2012) the application of virtual laboratories is an electronic learning process using computer simulations so that users can conduct experiments and simulate activities in the laboratory as if the user were in the actual laboratory. In addition, students can explain a concept based on experiments conducted online. Virtual laboratory also is a learning medium that is quite effective for students to understand scientific methods by conducting experiments.

Yuniarti et al. (2012) also revealed that virtual laboratories are simulations using computer devices such as conducting actual practice to improve understanding of concept studied as an introduction to practice and enrichment concepts. In addition, based on the results of preliminary research conducted by August et al. (2011), states that the learning presented through the integration of virtual concepts and science, technology, engineering and mathematics (STEM) makes the learning atmosphere more attractive and makes students socially oriented to their environment. This is expected to significantly improve practicum activities that are less helpful in building STEM skills.

From this explanantion, it can be concluded that STEM-based virtual laboratory is simulation of learning using computer technology that describes the simulation techniques of practicum activities in the laboratory as if real and integrated with the concept of science and the calculations in it. As a learning media product, STEM-based virtual laboratories provide opportunities for students to conduct experiments independently with or without internet access. To determine students' performance in the laboratory after the STEM-based virtual laboratory learning process, performance techniques and peer assessment are one of the tools that can be used. This assessment not only can be used to assess learning outcomes or products, but also can reveal the scientific attitudes of learners. This scientific attitude includes curiosity, love of truth, respect for facts, and respect for the need for communication in science (Singh \& Mishra, 2014). This assessment can measure students' knowledge, reasoning, skills, products, and also compound intelligence. Although during this pandemic conditions lecturers find difficulties to assess practicum activities faceto-face, through STEM-based virtual laboratory learning, assessments can still be carried out.

Legimin in Suryaningsih (2017) defines practicum as a learning method that plays a role in clarifying concepts through direct natural events, which supports and trains problem solving, applies knowledge and skills through situations at hand, trains in designing experiments, interpreting data, and training scientific work.

According to Hidayat (2018) and Kollar \& Fischer (2010) peer assessment is important, because collaborating and working in groups is the integral part of science learning. Peer assessment means making decisions based on individual responsibilities that benefit for their group. In peer assessment students are trained 
Performance and Peer Assessment Analysis Towards Students' Scientific Work Through STEM-Based Virtual Laboratory Learning

to communicate, write and report what they mean.

Muslich (2014) said that in practice peer assessment it is important to complete selfassessment. Peer assessment is unique in value, because students can receive criticism from friends for their work even though the criticism is also given by the teacher. Furthermore, research conducted by Thomas et al. (2011) and Rochmiyati (2013) related to the application of peer assessment on plant concepts and photosynthesis at secondary school level, showing that peer assessment can have impact on students' learning. Among others, it encourages students to understand their role in paired learning and make students able to learn autonomously. On the other hand, practicum activities are requirement of graduation from practicum courses in the Chemistry Education Study Program.

Based on the description above, it is considered important to analyze the application of performance and peer assessment through virtual STEM-based laboratory. The purpose of this study is to analyze the application of performance and peer assessment to students' scientific work through virtual STEM-based laboratory.

\section{RESEARCH METHOD}

This research uses Pre-Experimental Design method by using One Group Pretest-Posttest Design as research design to measure students' scientific work using performance assessment and to analyze peer assessment using One Shot Case Study. Fraenkel et al. (2011) mentioned the experimental design method as Weak Experimental Design, because this research method used a treatment sample group without a control sample.

In this research, students are treated by STEMbased virtual laboratory learning for some time $(X)$. Students are given initial observation sheet before treatment and final observation sheet after learning treatment through performance assessment instruments and then given after STEM-based virtual laboratory learning to analyze peer assessment. More details about the research design used in the study are shown in Table 1 and Table 2.

Table 1. Design of Pretest-Posttest in Control Group Design

\begin{tabular}{|c|c|c|}
\hline $\begin{array}{c}\text { Initial } \\
\text { Observation } \\
\text { Sheet }\end{array}$ & Treatment & $\begin{array}{c}\text { Final } \\
\text { Observation } \\
\text { Sheet }\end{array}$ \\
\hline $\mathrm{O}_{1}$ & $\mathrm{X}$ & $\mathrm{O}_{2}$ \\
\hline
\end{tabular}

Table 2. One Shot Case Study Design

\begin{tabular}{|c|c|}
\hline Treatment & $\begin{array}{c}\text { Peer Assesment } \\
\text { Questionnaire }\end{array}$ \\
\hline$X$ & $\mathrm{O}_{3}$ \\
\hline
\end{tabular}

This research started in July to September 2020 at Chemistry Education Department, one of universities in Indonesia. The subjects of this study were 99 students of the Chemistry Education Department who were still actively studying in the 2019/2020 Academic Year. The sample of this study was taken by 20 students of the class of 2018/2019 who had taken basic and advanced courses. The sampling process uses purposive sampling techniques with consideration that the students are taking course that has practicum as condition of graduation. In this research there are two kinds of variables, first is independent variables that are the application of performance and peer assessment through the study of STEM-based virtual laboratory and then dependent variable that is scientific work of students.

Students will take part in STEM-based virtual laboratory learning using V-lab and macromedia flash applications on acid-base titration experiment concept, $\mathrm{pH}$ determination and buffer solutions. Then scientific work during learning is measured using performance instruments and peer assessment. Collection of scientific work data using observation sheets conducted before and after learning activities. Observation is ongoing assessment technique by observing students' work directly using observation guidelines containing a number of behavior indicators. Practice of observation is used observation sheet in accordance with the rubric compiled. 
Observation sheets are made questions related to the indicators of each student's skills. The data obtained in this study is the value of the initial and final observation sheet. Performance assessment instrument data obtained through observation sheet will then be analyzed. To analyze the results of student's scientific work, the steps are to score on each indicator and then sum the score and calculate the final score in percentage form. For peer assessment, a questionnaire was used which was filled out by colleagues using the google form application. The data contained in the performance instrument and peer assessment were analyzed by calculating the percentage. Analysis of the student's observation sheet and questionnaire data using the formula:

$$
N P=\frac{R}{N S} X 100 \%
$$

Description:

NP : Percent value searched or expected

R : Number of scores obtained students or groups

NS : Maximum total score

The percentage of achievement results obtained is then calculated the average value to match the criteria that refer to the Purwanto assessment guidelines (2016) which can be seen in Table 3.

Table 3. Scientific Work Criteria from Observation Sheet Results

\begin{tabular}{|l|c|}
\hline \multicolumn{1}{|c|}{ Criteria } & Score \\
\hline Highly Competent & $85-100$ \\
\hline Competent & $65-85$ \\
\hline Incompetent & $45-65$ \\
\hline Highly Incompetent & $0-45$ \\
\hline
\end{tabular}

Furthermore, the data obtained in initial and final observation sheets will be calculated and analyzed scientific work using N-Gain analysis. The formula N-Gain (Munandar, 2009) as follows:

$$
N \text {-Gain }=\left[\frac{N_{B-N_{A}}}{N_{M A X}-N_{A}}\right] X 100 \%
$$

Description:

$\mathrm{N}_{\mathrm{A}} \quad=$ Initial value
$\mathrm{N}_{\mathrm{B}} \quad$ = Final value

$\mathrm{N}_{\text {MAX }}=$ Ideal value

After the value is processed, students' scientific work ability can be tested using one sample t-test. One Sample t-test is used to determine the average scientific work ability of each student whether it is better than the standard skill score or not. Students' scientific work is tested using paired sample t-test where samples are interconnected with each other. Paired samples are defined as a sample with the same subject but undergo two different treatments, namely pretest (before treatment) and posttest (after treatment) (Hartina et al., 2020).

\section{RESULT AND DISCUSSION}

The implementation of STEM-based virtual laboratory was well implemented by Chemistry Education Students through several applications including $\mathrm{V}$-lab on acid-base $\mathrm{pH}$ determination experiments, phet-simulation in acid-base titration experiments and students making practicum videos for buffer solution concept. The images of STEM-based $v$-lab forms displayed by students are as follows in Figure 1.

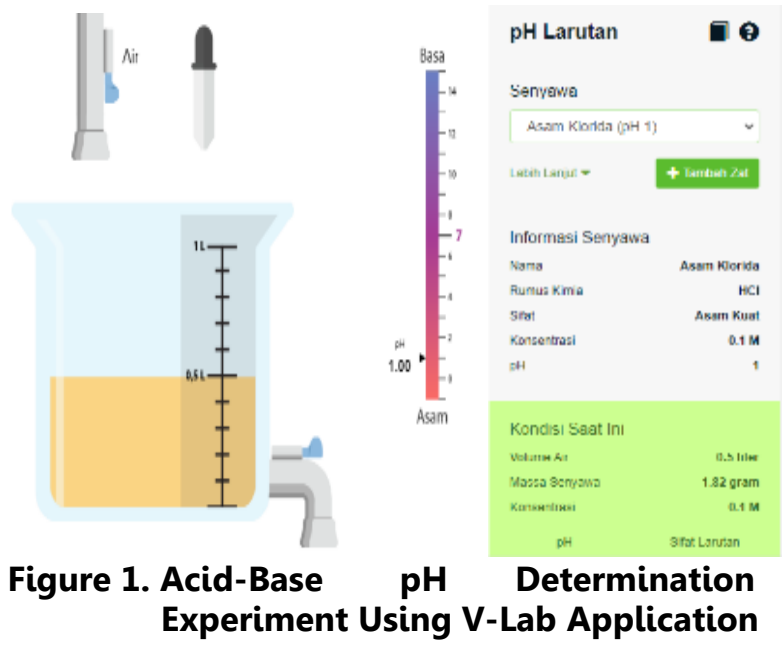

Data analysis of the implementation of performance assessment and peers in the form of percentage value adjusted to the students' scientific work indicators. The results of this research can be seen in the Table 4 . 
Table 4. Percentage of Performance and Peer Assessment of Students' Scientific Work Through the Implementation of STEM-Based Virtual Laboratory

\begin{tabular}{|l|l|c|c|c|}
\hline \multirow{2}{*}{ No } & \multicolumn{1}{|c|}{\begin{tabular}{c} 
Scientific Work Indicators \\
\cline { 3 - 4 }
\end{tabular}} & $\begin{array}{c}\text { Initial } \\
\text { Observation Sheet }\end{array}$ & $\begin{array}{c}\text { Final } \\
\text { Observation } \\
\text { Sheet }\end{array}$ & $\begin{array}{c}\text { Peer } \\
\text { Assessment } \\
\text { Questionnaire }\end{array}$ \\
\hline 1. & $\begin{array}{l}\text { Set up practicum presentation media } \\
\text { using V-Lab applications, macromedia } \\
\text { flash and practicum video. }\end{array}$ & $65 \%$ & $80 \%$ & $85 \%$ \\
\hline 2. & $\begin{array}{l}\text { Virtually explain practicum tools and } \\
\text { materials }\end{array}$ & $63 \%$ & $85 \%$ & $80 \%$ \\
\hline 3. & $\begin{array}{l}\text { Perform virtual practicum steps and } \\
\text { techniques according to work } \\
\text { procedures }\end{array}$ & $55 \%$ & $90 \%$ & $85 \%$ \\
\hline 4. & $\begin{array}{l}\text { Participate in groups on virtual } \\
\text { practicum activities }\end{array}$ & $65 \%$ & $80 \%$ & $75 \%$ \\
\hline 5. & $\begin{array}{l}\text { Communicate during virtual practicum } \\
\text { activities }\end{array}$ & $55 \%$ & $85 \%$ & $85 \%$ \\
\hline 6. & Describe virtual practicum results & $60 \%$ & $90 \%$ & $85 \%$ \\
\hline 7. & $\begin{array}{l}\text { Discussion of virtual practicum } \\
\text { observations and explaining } \\
\text { mathematical calculations }\end{array}$ & $60 \%$ & $85 \%$ & $90 \%$ \\
\hline 8. & $\begin{array}{l}\text { Making conclusions based on the } \\
\text { concepts of science, technology, } \\
\text { engineering and mathametics }\end{array}$ & $65 \%$ & & \\
\hline & \multicolumn{1}{|c|}{ Average Value } & $\mathbf{6 1 \%}$ & $\mathbf{8 6 \%}$ & $\mathbf{8 4 \%}$ \\
\hline
\end{tabular}

Based on students' performance and peer assessment results obtained through observation sheets and questionnaires, the average percentage for scientific work value through performance observation sheets after STEM-based virtual laboratory learning is at highly competent criteria, there is $86 \%$. For the assessment given by peers on competent criteria is $84 \%$. The highest percentage for performance observation sheets is in indicators of performing virtual practicum steps and techniques through V-Lab applications, macromedia flash and practicum video according to work procedures and creating opportunities for virtual practicum observations and discussions.

Thus, $\mathrm{N}$-gain data is used to see the difference in the initial and final observation value of implementation performance assessment. The average $\mathrm{N}$-gain is shown in Table 5 so it can be noted that the initial and final observation values have increased by 0.64 , this indicates it belongs to the medium category.
Table 5. N-gain Data of Initial and Final Observation Values

\begin{tabular}{|c|c|c|c|c|}
\hline Type & $\mathbf{N}_{\mathbf{A}}$ & $\mathbf{N}_{\mathbf{B}}$ & $\begin{array}{c}\text { Average } \\
\text { n-gain }\end{array}$ & Category \\
\hline $\begin{array}{l}\text { Performance } \\
\text { assessment }\end{array}$ & 61 & 86 & 0,64 & Medium \\
\hline
\end{tabular}

Paired sample t-test to test scientific work improvement was calculated before and after learning treatment. Data of paired sample ttest results can be seen in Table 6 .

Tabel 6. Paired sample test results t-test

\begin{tabular}{|c|c|c|c|}
\hline Paired & Mean & Df & Sig. (2 tailed) \\
\hline 1 & 73,31 & 20 & 0,000 \\
\hline
\end{tabular}

Paired sample t-test results in the value of the initial observation sheet and the end of scientific performance has a Sig value. (2tailed) below 0.05 , which is 0.000 where there is difference in average results of initial and final observations using performance assessment through STEM-based virtual laboratory learning. So it can be concluded that the application of performance affects the students' scientific work with average score of 
73.31 that has been determined significantly at the level of trust $95 \%$.

The student's scientific performance value is then analyzed with one sample t-test. This test is used to determine each of the average scientific work scores of the student's performance and peer assessment application whether it is better than the standard value of the skill. Test of one sample t-test for student's psychomotor ability can be seen in Table 7 .

Table 7. One Sample T-Test Results

\begin{tabular}{|l|c|c|}
\hline Parameter & $\begin{array}{c}\text { Performance } \\
\text { Assessment }\end{array}$ & $\begin{array}{c}\text { Peer } \\
\text { Assessment }\end{array}$ \\
\hline $\mathrm{T}$ & 1,725 & 1,725 \\
\hline Mean & 86 & 84 \\
\hline $\begin{array}{l}\text { Asymp.Sig.(2- } \\
\text { tailed) }\end{array}$ & 0,011 & 0,002 \\
\hline
\end{tabular}

The results of one sample t-test of students' scientific work ability were assessed using performance and peer assessment showed that Asymp's value. Sig (2-tailed) of 0.011 and 0.002 , it is smaller than 0.05 , this indicates that the average scientific work score of students is $>75$.

The application of performance and peer assessment in experimental activities in the laboratory can improve scientific work in making virtual practicum steps indicators according to work procedures, explaining virtual practicum results and creating opportunities for virtual practicum observations and discussions. This is due to the application of performance and peer assessment used to contain observation sheets and students' questionnaires needed in assessment using instruments such as learning scenarios, instrument grids, rubrics, and scoring guidelines as recapitulation of final grades and referring to assessment for learning so each stage of learning is given improvement feedback and assignments.

This is in accordance with the results of research conducted by Putri et al. (2016), stated that the science learning outcomes obtained using a scientific approach-based performance appraisal instrument are higher than ordinary learning, which is $82.11>70.79$.
So it can be concluded that the application of performance assessment instruments affects science learning outcomes, especially on psychomotor skills.

Performing virtual practicum steps and techniques through V-Lab applications, macromedia flash and practicum video according to work procedures obtained the highest score of $90 \%$. This means that in this indicator students have prepared the material and presented the results of practicum very well. The results of this study are in accordance with research conducted by Sarah \& Padmaningrum (2018) showed that by applying the concept of virtual lab-based chemical practicum, students are able to investigate every problem and learn to work independently and prepare their own experimental tools and materials as a form of problem solving when practicing. Furthermore, the results of the application of peer assessment of the highest percentage was found in indicator of discussing virtual practicum observation results and explaining the calculation mathematically. Peer assessments are given after each practicum was completed. Through peer assessment, friends' learning ability can be measured.

As stated by Anshari et al. (2014) that peer ratings can help reveal person's ability to work together, think critically about the process and results of practicum and help receive feedback or criticism from others. This peer assessment is able to encourage students to have sense of responsibility to the practicum process so they can learn independently, train evaluation skills that are useful for lifelong learning and encourage deep learning.

In addition to students' ability to prepare and conclude presentations using STEM-based virtual laboratory learning media, students are motivated to present concepts with attractive and easy-to-understand look. The use of virtual laboratories is able to minimize the misconceptions of abstract concepts. The existence of virtual explanation is able to open the insights of chemistry education students on the concept of acid-base, natural materials and organic as a whole.

This is an open access article under CC-BY-SA license (https://creativecommons.org/licenses/by-sa/4.0/) 
Performance and Peer Assessment Analysis Towards Students' Scientific Work Through STEM-Based Virtual Laboratory Learning

This result is also in accordance with the research of Nomleni et al. (2018) that the visualization of concepts displayed in interesting and relevant way can improve the understanding of concepts about the key and visual properties and video content that can be heard, seen to serve as substantial learning tool. In the era of digital literacy where the flow of information is abundant, students need to have the ability to choose relevant sources and information, find quality sources and assess sources from aspects of objectivity, reliability, and dissority.

Based on the results of the research, the application of performance and peer assessment through STEM-based virtual laboratory learning can improve the scientific work of students. In addition, STEM-based virtual learning can also minimize misconceptions that often occur in chemical learning processes.

\section{CONCLUSION}

Based on the results of the research, it can be concluded that the application of performance and peer assessment to the scientific work of students through STEM-based virtual laboratory learning is in the criteria of highly competent $86 \%$ and competent $84 \%$. The results of paired sample t-test of students' scientific work ability are assessed using performance assessment has Sig value. (2tailed) below 0.05 , which is 0.000 where there is a difference in average results of initial and final observations using performance assessment through STEM-based virtual laboratory learning. The results of one sample t-test of students' scientific work ability are assessed using performance and peer assessment has sig value. (2- tailed) 0.011 and 0.002 , this means that the average scientific work score of students $>75$.

\section{ACKNOWLEDGEMENT}

Gratitude is conveyed to the Ministry of Research, Technology and Higher Education for the assistance of Research Funds for Leading Lecturers in accordance with Decree number 545/UN54.6/PG/2020. Furthermore, the LPPM team which has facilitated, the Chemistry Laboratory Assistant, and the lecturers of the Chemistry Education Study Program of the Faculty of Teacher Training and Education Universitas Samudra who have contributed to the implementation of this research. 
Performance and Peer Assessment Analysis Toward Students' Scientific Work Through Learning STEM-Based Virtual Laboratory

\section{REFERENCES}

Adam, S. (2015). Pemanfaatan Media Pembelajaran Berbasis Teknologi Informasi bagi Siswa Kelas X SMA Ananda Batam. Computer Based Information System Journal, 3(2). Retrieved from http://ejournal.upbatam.ac.id/index.php /cbis/article/view/400

Anshari, H., Kusairi, S., \& Sugiyanto. (2014). Pengembangan Model Penilaian PeerSelf Assessment Termoderasi Guru Berbasis Web untuk Pelajaran Fisika SMA. Jurnal Mahasiswa dan Dosen Fisika, 3(1), 1-2. Retrieved from http://jurnalonline.um.ac.id/article/do/detailarticle/1/35/1935

August, S. E., Neyer, A., Murphy, D. B., Themes, R. Q., Hammer, M., Shoktgozar, D., \& Vales, J. (2011). Engaging Student in STEM Education through a Virtual Learning Lab. Conference American Society Engineering Education (ASEE). 10.18260/1-2--17854

Fraenkel, J. R., Wallen, N. E., \& Hyun, H. H. (2011). How to Design and Evaluate research in Education 8th Ed. New York: McGraw-Hill.

Hartina, L., Rosidin, U., \& Suyatna, A. (2020). Pengaruh Penerapan Instrumen Performance Assessment pada Pembelajaran IPA Berbasis Laboratorium Real terhadap Hasil Belajar Siswa. Jurnal Penelitian Pendidikan IPA (JPPIPA), 6(1), 25-31. 10.29303/jppipa.v6i1.299

Hidayat, A. (2018). Meta Analisis: Pentingnya Self dan Peer Assesment dalam Pembelajaran. Jurnal Basicedu, 2(1), 95101.

https://doi.org/10.31004/basicedu.v2i1. 127
Jaya, H. (2012). Pengembangan Laboratorium Virtual untuk Kegiatan Praktikum dan Memfasilitasi Pendidikan Karakter di SMK. Jurnal Pendidikan Vokasi, 2(1), 8190. https://doi.org/10.21831/jpv.v2i1.1019

Kollar, I., \& Fischer, F. (2010). Peer Assessment as Collaborative Learning: A Cognitive Perspective. Learning and Instruction, 20(4), 344-348. https://doi.org/10.1016/j.learninstruc.20 09.08.005

Munandar, U. (2009). Pengembangan Kreativitas Anak Berbakat. Jakarta: Rineka Cipta.

Muslich, K. M. (2014). Pengembangan Model Assessment Afektif Berbasis Self Assessment dan Peer Assessment di SMA Negeri 1 Kebomas. Jurnal Kebijakan dan Pengembangan Pendidikan, 2(2). https://doi.org/10.22219/jkpp.v2i2.1912

Nomleni, F. T., \& Manu, T. S. N. (2018). Pengembangan Media Audio Visual dan Alat Peraga dalam Meningkatkan Pemahaman Konsep dan Pemecahan Masalah. Scholaria: Jurnal Pendidikan dan Kebudayaan, 8(3), 219-230. https://doi.org/10.24246/j.js.2018.v8.i3. p219-230

Purwanto. (2016). Evaluasi Hasil Belajar. Yogyakarta: Pustaka Pelajar.

Putri, M. R. A., Rosidin, U., \& Wahyudi, I. (2016). Perbandingan Hasil Belajar Sains Menggunakan Performance Assessment Bebasis Scientific Approach dengan Performance Assessment Konvensional. Jurnal Pembelajaran Fisika, 4, 78. Retrieved from http://jurnal.fkip.unila.ac.id/index.php/J PF/article/view/10768

Rochmiyati. (2013). Peer Assessment Model on Collaborative Elaboration Learning for

Jurnal Tadris Kimiya 5, 2 (December 2020): 204-212 
Performance and Peer Assessment Analysis Towards Students' Scientific Work Through STEM-Based Virtual Laboratory Learning

Interdisciplinary Social Studies in The Junior High Schools. Jurnal Penelitian dan Evaluasi Pendidikan, 2, 333-346. https://doi.org/10.21831/pep.v17i2.170 4

Sabekti, A. W., \& Adriani, N. (2019). Pemanfaatan Teknologi Android dalam Pembelajaran Kimia untuk Meningkatkan Daya Saing Bangsa. Talenta Conference Series: Science and Technology, https://doi.org/10.32734/st.v2i2.516

Sarah, \& Padmaningrum, R. T. (2018). Pengaruh Penerapan Virtual Laboratory Terhadap Kemampuan Investigasi dan Prestasi Belajar Peserta Didik. Jurnal Pembelajaran Kimia, 7(5), 184-192. Retrieved from http://journal.student.uny.ac.id/ojs/inde x.php/pkimia/article/view/13379

Sari, E. S., \& Pujiono, S. (2017). Budaya Literasi di Kalangan Mahasiswa FBS UNY. Jurnal Litera, 16(1). https://doi.org/10.21831/ltr.v16i1.14254

Singh, U., \& Mishra, P. (2014). Study of Scientific Attitude of B.ED. and B.ED. (Special) Pupil Teachers. Scholarly Research Journal for Interdisciplinary Studies, 2(13), 1815-1822. Retrieved from http://oaji.net/articles/2014/11741411723581.pdf

Suryaningsih, Y. (2017). Pembelajaran Berbasis Praktikum Sebagai Sarana Siswa untuk Berlatih Menerapkan Keterampilan Proses Sains dalam Materi Biologi. Jurnal Bio Education, 2(2), 49-57. http://dx.doi.org/10.31949/be.v2i2.759

Thomas, G., Martin, D., \& Pleasants, K. (2011). Using Self- and Peer-Assessment to Enhance Students' Future-Learning in Higher Education. Journal of University Teaching \& Learning Practice, 8(1), 1- 16. Retrieved from https://eric.ed.gov/?id=EJ940101
Yuniarti, F., Dewi, P., \& Susanti, R. (2012). Pengembangan Virtual Laboratory Sebagai Media Pembelajaran Berbasis Komputer pada Materi Pembiakan Virus. Unnes Journal of Biology Education, 1 (1),27. https://doi.org/10.15294/jbe.v1i1.371 